\title{
HBV Surface Antibody Level Result
}

National Cancer Institute

\section{Source}

National Cancer Institute. HBV Surface Antibody Level Result. NCI Thesaurus. Code C157502.

The quantity of hepatitis b virus surface antibody in a sample. 